\title{
Things Fall Apart - Rebel Fragmentation in Syria's Civil War (2011-2017)
}

\author{
Patrick Steen Pedersen, Royal Danish Defence College, pape@fak.dk \\ Olivier J. Walther, University of Florida and University of Southern Denmark, \\ owalther@ufl.edu
}

20 June 2018

\begin{abstract}
In rebel-held Syria, an array of rebel organisations are nominally allied in their fight against the Syrian government and yet they remain internally divided. Rather than being a rare occurrence, fragmentation within rebel movements is a common phenomenon with wide-ranging consequences for its chances of success. The objective of this paper is to explain what has caused fragmented to occur in Syria from 2011 to 2017. Using a three-dimensional conceptualisation of rebel fragmentation, we identify and analyse the causes of rebel fragmentation within the Syrian rebel movement and illustrate how these dynamics have influenced the overall degree of fragmentation throughout four phases of the conflict. The study finds that the splintering of the Syrian rebel movement is a second-order effect of historical, structural and geopolitical factors generally outside the immediate control of the non-state actors.
\end{abstract}

\section{Keywords}

rebellion, fragmentation, war, alliances, Al Qaeda, Syria, Turkey

\section{The puzzle}

The Syrian rebel movement consists of hundreds of factions operating under dozens of separate organisational command structures. Despite the concerted efforts by internal and external parties to establish intra-movement coherence, deep divisions and widespread infighting between nominal allies continue to debilitate the rebels. Inter-rebel alliances remain inherently unstable and, as new alliances form and organisations coalesce, other frameworks of cooperation dissolve and collapse. Often, the breakdown of alliances and reconfiguration of the balance of power culminates in territorial skirmishes, assassinations and out-right inter-rebel civil war. Rather than coalescing into a unified rebel front, rebel groups continue to compete for power amongst themselves, thus failing to develop lasting structures of governance and political authority that cut across factional divides, enclaves and provincial boundaries. 
The fragmentation of the Syrian rebel movement is not unique. Rather, rebel fragmentation is a widespread phenomenon: roughly $44 \%$ of the armed opposition movements engaged in 114 civil wars since 1989 experienced fragmentation ${ }^{1}$. Moreover, its implications for materially inferior rebel movements are well documented ${ }^{2}$. Disunity diverts energy away from the fight against the incumbent regime and heightens the level of wanton violence employed against civilians. It also erodes political legitimacy, enables regimes to employ "divide and conquer" strategies $^{3}$, increases the chances of rebel defections to the state and severely complicates civil war negotiations.

Seen in that light, the degree of fragmentation and the regular occurrence of fratricidal violence within the Syrian rebel movement seems almost incomprehensible. Nested within this empirical puzzle is also a theoretical one: despite the fact that inter-rebel violence is a common phenomenon and its consequences are clear, the mechanisms causing fragmentation and infighting within rebel movements remain poorly understood ${ }^{4}$. While several positivist studies have studied the phenomenon over the last years, there remains a pronounced demand to move beyond the quantitative framework and instead provide systematic case studies of rebel fragmentation and infighting between nominally allied rebel organisations ${ }^{5}$.

By examining the ongoing conflict in Syria, this paper seeks to contribute the growing body of intrastate conflict research, which revolves around the phenomenon of rebel fragmentation and how it affects rebel movements battling incumbent regimes. What has caused the Syrian rebel movement to fragment from 2011 to 2017? The study finds that the splintering of the Syrian rebel movement is a second-order effect of historical, structural and geopolitical factors outside the immediate control of the non-state actors. These findings are highly relevant to our understanding of why Syria's civil war has developed into a Gordian knot. Exploring the causal mechanisms of fragmentation within Syria's rebel movement not only reveals important insights into how we can make sense of the often paradoxical nature of inter-rebel relations.

\section{Internal divisions within rebel movements}

Rebel fragmentation and infighting occur within a movement and among the organisations that comprise it. Sandwiched in between macro- and micro-level of analysis lies the meso- 
level whose primary units of analysis are groups, local elites and communities. In order to understand the mechanisms causing fragmentation and infighting, focusing on this layer of analysis is likely more fruitful than the other two scopes ${ }^{6}$. Recent quantitative meso-level studies have turned their attention to how rebel fragmentation affects patterns of violence ${ }^{7}$, indicating that a lack of intra-movement cohesion heightens the level of violence directed not only against the incumbent government, but also against civilians who increasingly fall victim to rape, kidnapping, looting and murder ${ }^{8}$. Some quantitative studies have examined how an increasing number of veto players prolong the duration of multiparty civil wars ${ }^{9}$, while others have investigated how decreased interdependency and cooperation between rebel groups affect their chances of success against their common enemy ${ }^{10}$. Their conclusions emphasize that fragmentation is risky, destructive and resource consuming.

Yet, rebel organisations spend a considerable amount of time and resources fighting each other when they could be fighting the government. Quantitative studies of intra-state conflicts 1989 and 2007 show, for example, that the probability of infighting between rebel organisations is significantly higher when they are engaged in areas with drug cultivation; when they exercise territorial control vis-à-vis the state; when groups are either weak or strong; and when groups receive material support from foreign states ${ }^{11}$. A more recent study conducted on intrastate armed conflicts between 1975 and 2013 show that fragmentation depends on the structural and strategic barriers to entry that nascent rebel groups face while entering a conflict $^{12}$. Groups that can rely on strong ethnic networks or share a similar leftist ideology are less prone to fragmentation.

Despite the prevalence of the phenomenon, the theoretical understanding of why fragmentation occurs remains relatively underdeveloped. As one of the few researchers to tackle this issue in a comprehensive manner, Christia ${ }^{13}$ argues that rational power considerations drive the formation and fracturing of rebel alliances. By applying the core concepts of neorealist structuralism to intra-state conflict scenarios, the author largely dismisses the importance of identity and ideology in shaping and structuring intra-movement relations. Instead, she argues that rebel organisations will attempt to establish or embed themselves in a 'minimum winning coalition' possessing "enough aggregate power to win the conflict, but with as few partners as possible so that the group can maximise its share of post-war political control"14. 
A preliminary analysis of how organisations within the Syrian rebel movement have chosen to align themselves indicates that ideology does actually play a significant role in alliance building. This does not mean that these frameworks of cooperation are immune to splits, that infighting does not occur between ideologically aligned organisations or that organisations of different ideological beliefs do not cooperate in Syria. However, the minimum winning coalition theory suggests that fragmentation is a result of deliberate calculations rather than a complex set of causal mechanisms that may be outside the control of the individual organisations and their leaderships. Unlike states in a structural neorealist world, rebel organisations do not operate in a closed system but are rather subjected to a wide range of influences that may affect and limit their behaviour.

Taking a more holistic approach, Bakke et al. ${ }^{15}$ suggest that divisions within a rebel movement can be explained by examining how numerous, institutionalized and powerful are the organisations within a conflict. They argue that the risk of violent fragmentation is most likely when many factions - with weak institutional ties between them - distribute power diffusely among them. This institutional approach does not aspire to discover the causal mechanisms of rebel fragmentation as such. Rather, their three-dimensional conceptualisation provides a useful prism through which the complexities of the conflict can be analysed in a systematic fashion. The study represents an important step in expanding our knowledge of interrebel dynamics as well as how variations in the overall degree fragmentation affects the likelihood and character of infighting.

\section{Rebel fragmentation as a multidimensional concept}

As a reaction against the tendency to regard armed rebel movements as coherent challengers to the state, Bakke et al. ${ }^{16}$ propose an interpretation of rebel movements as being comprised of a shifting set of actors who share a central identity but may also engage in malleable allegiances and possess diametrically opposing interests. Consequently, the organisations that constitute a movement will all claim to share the same overarching identity but will also possess and pursue their own particular interests. It is in this nexus between common purposes of the movement and private interests of its constituent organisations that fragmentation occurs. As organisations compete for leadership and influence among the same constituency, dual contests within a movement can erupt and lead to infighting. Fragmentation can be conceptualised by examining three constitutive, interconnected dimensions of this phenomenon. 
The first variable that affects the overall level of fragmentation is the number of organisations that exist within the rebel movement. Although the existence of many organisations within a movement indicates the existence of a multitude of internal differences and divergences, numerically fragmented movements may still be internally balanced if they manage to pursue their collective interests in concert. Conversely, a rebel movement consisting of only two organisations may suffer from crippling conflicts of interest and strategy, which may devolve into internecine infighting between two competing centres of gravity.

The second variable in determining the degree of fragmentation is the level of institutionalisation that exists between the organisations. Cohesive movements are characterised by the existence of strong, durable institutional links that tie the organisations together and coordinate their behaviour, while fragmented movements lack the networks and structures that makes coordinated military and political action possible. Superior cohesion and discipline are essential traits of organisational control. Overarching institutional structures such as intra-organisational alliances, central committees and practices of coordination with exiled rebelgovernments have a cohesive effect on the entire movement. They require that the institutional structures possess breadth and depth to produce political synchronisation, coordinate strategic efforts and constrain the actors included in the institutional framework. Movements that manage to establish a strong institutional web will develop state-like attributes, sometimes resulting in a complete amalgamation of the constituent organisations.

The third variable that affects the overall level of fragmentation is how power is distributed within the rebel movement. In movements dominated by one hegemonic organisation, the consequences of being divided into numerous organisations are diminished, as the ability of subordinate organisation to affect the collective goals of the movement is limited. Conversely, when power is dispersed across numerous organisations, the risk of fragmentation rises as it opens up windows of opportunity for individual factions to pursue their private interests. In their model, Bakke et al. ${ }^{17}$ employ a holistic conception of power, which encompasses material resources such as financial revenue and factors such as ideology, popular support and perceived legitimacy. Variations in access to these factors can explain fluctuating patterns of power distribution.

When combining the variables, it becomes possible to form a three-dimensional conceptualisation of fragmentation. If a movement consists of numerous organisations with weak or no 
interconnecting institutional links and power is dispersed among the groups, the movement is likely to be extremely fragmented. In contrast, a movement consisting of few organisations that are tied together by strong institutional links while power is concentrated in one hegemonic organisation, will most probably be extremely cohesive.

The internal make-up of a rebel movement is constantly subject to change. New groups emerge while others are eliminated; alliances form as other frameworks of cooperation break down; power fluctuates among the organisations as the conflict evolves and a flurry of factors shape how influence is distributed. These changes will lead to different patterns of infighting within the movement. For instance, a highly institutionalised movement consisting of many organisations with power dispersed among the actors carries a relatively low probability of infighting. If infighting does occur in this configuration, it will likely involve new organisations that arise to challenge the organisations within the institution or involve existing organisations that defect. Conversely, in movements consisting of many organisations with a weak degree institutionalisation, but where power is heavily concentrated, infighting is likely to involve the strongest organisation as it is challenged or it targets others in order to remain hegemonic.

In the subsequent analysis of what has caused the Syrian rebel movement to fragment, Bakke et al.'s model will be used as a prism through which the intra-movement dynamics of the rebels is analysed. By dividing the conflict into four different temporal phases, it becomes possible to identify, describe and analyse the cases of fragmentation as well as to illustrate the development of various patterns of fragmentation throughout the conflict.

\section{The fragmentation of the Syrian rebel movement as an extreme case}

While rebel fragmentation is indeed a common phenomenon in civil conflicts, Syria does represent an extreme case ${ }^{18}$. Few conflicts have seen a similar degree of numerical fragmentation, which makes the fragmentation of the Syrian rebel movement particularly suitable for examination through a single-case research design. Choosing an extreme case of rebel fragmentation is likely to provide significantly more information on the causes of the phenomenon than a more representative case in which the symptoms are less pronounced. 
The conflict revolves around four different blocks of actors; the Syrian state, its armed forces and paramilitary loyalists; the rebel movement consisting of a multitude of anti-regime organisations; Syrian Kurdish organisations such as the People's Protection Units (YPG); and the so-called Islamic State. Despite the fact that the rebels appear to be mobilised around a clear collective identity and fight a common enemy, claims of inter-rebel unity has remained a mirage since the beginning of the conflict. Being Sunni-Arab and subscribing to related, albeit varying, visions of a future political order for Syria does not guarantee intra-movement coherence. While shared identities and group interests may shape and structure the primary actor blocs of a conflict, such commonalities do not constitute a safeguard against the exercise of violence within a movement

As is often the case when dealing with ongoing, highly dynamic conflicts, access to reliable data is inherently limited. Not only does chaos and confusion create substantial uncertainty about seemingly basic information; the active parties may also have reasons to obscure the facts on the ground, which often remains inaccessible to researchers ${ }^{19}$. Cutting through the flurry of propagandised information is essential in order to obtain reliable qualitative data and doing that requires choosing sources with great care. To that end, this paper primarily draws on two types of sources, namely Stanford University's Mapping Militant Organisations ${ }^{20}$ dataset, and a wide array of secondary sources such as journal articles and recently published books on Syria's civil war. Select primary sources from armed groups and the government will also be included albeit with significant caveats.

\section{Four phases of fragmentation}

By dividing the conflict into four temporal phases, we illustrate the complex and dynamic nature of the fragmentation phenomenon. Each phase is chronologically analysed through Bakke et al.'s three-dimensional model after which the degree of fragmentation in each temporal phase is mapped to show how the fragmentary dynamics influences the internal composition of the rebel movement.

\section{Phase I: Formation (March 2011 - July 2012)}

The first period spans from the onset of the conflict in early 2011 to the degradation of the Free Syrian Army as a centralized organization in the summer of 2012. It shows that the seeds of division were already planted before the war started and that attempts to forge interrebel unity not only failed but also exacerbated the fragmentation of Syria's rebel movement. 


\section{Fragmented origins}

The strongly authoritarian Syrian states did not provide a conducive environment for the formation of coherent rebel movements. For more than four decades, all forms of political dissent have been effectively suppressed by the state apparatus, which was built upon the monopolistic powers of the ruling Baath-party, the unquestioned and cult-like status of the alAssad family and a vast security apparatus that sought to control all aspects of social, civil and political life. Consequently, Syria's pre-war political opposition, which primarily consisted of intellectual and elite-centric dissidents, was deeply dysfunctional, bereft of organisational structure, political visions and democratic dialogue ${ }^{21}$. Because civil-society groups and political associations were not allowed to form and operate without the approval of all thirteen branches of the security apparatus, no substantial, independent organizational outlets through which popular discontent could be vented existed prior to the uprisings ${ }^{22}$.

The circumscribed state of Syria's pre-war civil society had vast implications for how the popular discontent manifested itself once the widespread protests gradually transformed into an armed struggle during the summer of 2011. The absence of pre-existing organizations through which the popular uprising could be mobilised severely thwarted the degree to which the opposition to the Assad regime could manifest itself. Rather than growing organically from pre-existing civil society associations, trade unions or independent political parties, the armed rebellion sprouted diffusely through spontaneously formed neighbourhood militias, makeshift committees and small cell-based underground opposition networks that rarely had any ties to existing political groups ${ }^{23}$. As such, the Syrian rebel movement was structurally preconditioned to fragment from the onset of the conflict.

\section{The rise of the Free Syrian Army}

In response to the increasingly violent crackdowns on protesters, the opposition to the Assad regime became increasingly militarized. The formation of the Free Syrian Army (FSA) in July 2011 marked an attempt to form an organisational body that possessed the ability to coordinate the armed struggle across the dispersed, but rapidly proliferating pockets of resistance. By March 2012, thousands of defecting soldiers and officers had joined the FSA under the command of Col. Riad al-Assad who, along with a range of high-ranking defectors from the Syrian Army and intelligence branches, attempted to coordinate the armed struggle from an airbase in southern Turkey ${ }^{24}$. 
In the early days of the conflict, the FSA, with its nationalist aspirations symbolized by its adoption of pre-Baathist Syrian flag, was indeed a growing organisation. As self-established units spontaneously formed throughout the country, the leading commanders would typically announce their allegiance to the FSA even though they rarely had any form of relationship to its exiled leadership ${ }^{25}$. Simultaneously, a range of other organisations formed outside the FSA-framework. Lacking the recruitment capabilities, popular legitimacy and external ties of the FSA, these Islamist, Salafist and Jihadist organisations generally kept a low profile. Usurping the popular rhetoric of the uprising, they ostensibly supported the FSA and accepted its tactical and strategic leadership in coordinating offensives throughout the country. Even Jabhat al-Nusra, al-Qaeda's Syrian affiliate, accepted its subordinate role during a string of FSA-coordinated raids on army checkpoints in Damascus during the spring of 2012.

For a time, the FSA appears to have possessed the required power - in material, ideational and relational sense - to function as a nearly hegemonic anchor within the numerically fragmented movement. While the FSA undoubtedly suffered from crippling structural deficiencies that ultimately undermined it, the organisation did succeed in established itself as a popular, revolutionary firebrand.

\section{Failing to build a functioning institutional framework:}

Building institutional links between the organisations within a movement is necessary to outline cross-organisational rules, cultivate shared norms that regulate and constrain the armed actors on the ground and build effective and legitimate political structures. Well aware of the need to lead and shape events on the ground rather than just reacting to them, the rebel movement - including activists and politicians within and outside the country - attempted to build a framework through which cooperation could be cultivated.

Local Coordination Committees (LCCs) were formed throughout the rebel-held areas. Besides providing basic civil services, the LCCs sought to streamline the rebel movement's communication to the regional and global audiences ${ }^{26}$. Internally, however, the LCCs suffered from lacking oversight and strategic coordination. While some were able to coordinate their efforts effectively, others became tools of power for local clans and emerging warlords ostensibly operating under the FSA banner ${ }^{27}$. Often riddled with corruption and engaging in 
conflicts between families from adjacent rural towns, the LCCs lacked the legitimacy as well as the funds to fill the governmental vacuum left behind by the contracting state ${ }^{28}$.

As the complex web of LCCs continued to expand, the need to centralise local authority became increasingly apparent. Earlier, in the fall of 2011, the Syrian National Council (SNC) had been established in Turkey under heavy Qatari influence. Inspired by the fall of Muammar Gaddafi in Libya, the political opposition body began agitating for Western military intervention while attempting to lay the groundwork for a future political transition process ${ }^{29}$. In March 2012, the FSA and the SNC agreed to join forces, thus transforming the rebel firebrand into the official armed wing of Syria's government-in-exile. Donations and weapons were supposed to flow through this framework in order to ensure that money and material ended up in the right hands ${ }^{30}$.

In theory, the attempt to establish a revolutionary triad by merging the military dimension of the Free Syrian Army with local governance networks of the LCCs and the SNC made sense. Theoretically, a highly institutionalised movement will develop state-like features that constrain the actors within it through enforceable rules and functional structures of governance. Furthermore, establishing an overarching political structure not only carries a practical function in centralising local governance and assisting in coordinating the armed struggle; it can also imbue the rebel organisations with an air of legitimacy in the eyes of the international community $^{31}$.

In practice, however, shaping an exiled opposition body with enough legitimacy to exercise political authority inside war-torn Syria while catering to the international community proved impossible (Figure 1). One of the main reasons why the attempt to institutionalise the struggle failed was the existence of an insurmountable credibility gap between the armed actors and the exiled political figures ${ }^{32}$. Often referred to as the "five-star hotel opposition" by the rebels on the ground, the SNC found itself in a precarious position as the increasingly autonomous and ideologically disparate FSA-factions would only give the diaspora-dominated opposition body a very limited mandate ${ }^{33}$.

Meanwhile, the international backers of the SNC demanded that it had to present a "coherent unified vision of the Syria they want of the future" ${ }^{\text {"34 }}$. This proved impossible to perform as the exiled SNC members did not possess the required leverage to influence the internal politics of 
the essentially rudderless rebel movement. Inside the rebel-held areas, the conflict continued to escalate, setting off volatile dynamics that soon crippled the legitimacy of the SNC and side-lined the FSA as independent rebel organisations began to proliferate.

Figure 1: Fragmentation in Phase I

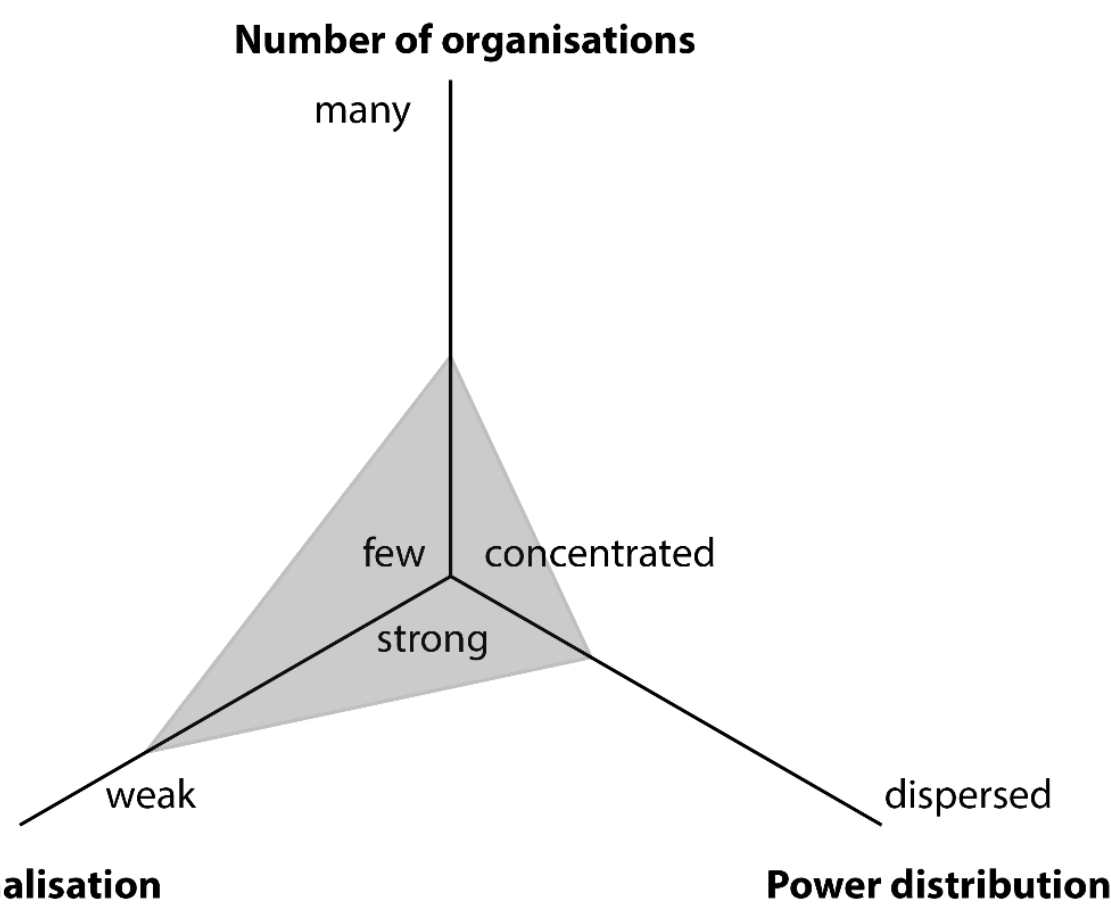

Phase II: Disequilibrium (July 2012 - July 2014)

The second phase of the Syrian conflict began with the gradual disintegration of the FSA. It was marked by the rapid proliferation of armed groups that either formed autonomously or splintered off from the FSA structure, thus challenging its position as the hegemonic anchor of the rebel movement. Despite the formation of new intra-movement coalitions, the rising organisations failed to evolve strong institutional structures capable of unifying the movement.

\section{Proliferation}

At least two factors led to the proliferation of rebel organisations during Phase II: the gradual collapse of the FSA as a centralised organisation and changing patterns in financial and military aid provided to the rebels by patron states in the region. 
The enlargement of territory under rebel control strained the FSA's already weak command and control structures. Consequently, it became increasingly difficult to exercise tactical control over the individual units and their operations. As an increasing number of untrained civilians from the newly captured territories were enrolled into the FSA, military discipline weakened. Looting was widespread and extensive; kidnapping of suspected regime collaborators became a source of income and violence against civilians in the rebel held areas was excessively used ${ }^{35}$. The growing tendency towards criminality severely tarnished the reputation of the FSA and gradually chipped away its popular legitimacy as the underlying, structural deficiencies of the wider organisation were exposed. Its inability to effectively manage its units on the ground made room for factions within the FSA, such as the Aleppo-based Islamist organization Liwa al-Tawhid.

The increasing interference by the regional stakeholders also exacerbated the proliferation of organisations. The politico-military framework established by external state backers to coordinate the struggle against the Assad regime simultaneously became a venue for regional competition between Turkey, Qatar and Saudi Arabia. In November 2012, as part of a U.S.led attempt to reboot the political extension of the rebel movement, the National Coalition for Syrian Revolutionary and Opposition Forces (the Coalition) was established. This new framework sought to close the gap between the armed actors, the LCCs and the exiled opposition ${ }^{36}$.

Simultaneously, the rebel command structure was overhauled in an attempt to accommodate the new intra-rebel balance of power. The Supreme Military Council (SMC) tasked with centralising command over the increasingly disparate FSA-affiliated factions and independent non-jihadist Islamist organisations sought to regain control over the flow of military supplies and funds from the regional powers and the rebel movement's Western state backers ${ }^{37}$. However, not only were the arms shipments and financial contributions often earmarked to specific groups by the respective donor states in the region ${ }^{38}$; many organisations simultaneously continued to receive foreign state funding through backchannels while ostensibly supporting the new politico-military institutional framework. Particularly Saudi Arabia and Qatar kept funnelling money and weapons to select organisations ${ }^{39}$ while cultivating inter-rebel alliances of their own that began forming inside the SMC-framework.

External sponsorship also tended to introduce exogenous interests into the dispute, exacerbating dormant competitive dynamics within the rebel movement. The SMC became a venue for 
inter-regional competition between state patrons who sought to strengthen their own preferred organisations and forge micro-alliances within the SMC structure. Fearing the potential blowback of Qatar's scattershot funding of secularists, Islamists, Salafists and Jihadists alike, Saudi Arabia sought to increase its influence within the SMC in order to tip the balance in favour of the crumbling FSA structure. Meanwhile, Qatar increasingly outsourced its fundraising measures to an expanding pool of middlemen ${ }^{40}$, thus directly counteracting the Saudi attempt to strengthen the SMC and exacerbating the proliferation of organisations operating on the battlefield. As a result, the inter-regional rivalry undermined the SMC legitimacy that is essential for a numerically fragmented rebel movement to possess if it is to maintain a relatively high degree of internal coherence and optimise resource and information sharing.

\section{Inter-rebel multipolarity}

The splintering of the FSA was a symptom of its degradation from a centralised organisation with a capacity to coordinate combat operations across Syria to a franchise whose revolutionary iconography continued to live on as the organisational structure gradually came apart.

In northwestern Syria, Ahrar al-Sham and Jabhat al-Nusra absorbed and usurped the crumbling FSA-factions. Both successfully integrated themselves into the rebel landscape during the second phase of the conflict as they transformed into competing and yet closely interconnected centres of gravity around which other organisations would cluster throughout the conflict. Ahrar al-Sham, a nationally oriented Salafist organisation, had grown from relative obscurity during the early days of the insurgency to a powerful local actor with very close ties to Turkey and Qatar. In mid-2012, it headed the formation of the Syrian Islamic Front, an alliance consisting of Salafist organisations that had remained outside the SMC-framework. Similarly, Jabhat al-Nusra had had gradually become a reliable partner for most rebel organisations within the movement despite of its ties to al-Qaeda's international leadership.

Theoretically, a multipolar inter-rebel configuration does not necessarily lead to a heightened risk of infighting if there are institutional links through which power and responsibilities can duly be delegated ${ }^{41}$. Similarly, the existence of multiple strong rebel organisations can be an advantage if their internal affiliations remain positive ${ }^{42}$. Indeed, in Syria, despite the proliferating number of organisations and the emergence of powerful actors that circumvented the initial hegemony of the FSA, infighting rarely occurred during the second phase of the conflict. 


\section{Ad-hoc alliance-building, part 1}

On November 22, 2013, seven of Syria's most powerful rebel organisations, including Jaysh al-Islam and Ahrar al-Sham, announced the formation of the Islamic Front. With up to 70,000 men, the new Islamist alliance would become Syria's most powerful insurgent bloc ${ }^{43}$. At the time of the Islamic Front's formation, it became obvious that the Coalition and FSA-SMCstructure, much like the framework established during the conflict's first phase, were not able to forge internal coherence within the rebel movement. The failure of the rebels to muster international support for launching retaliatory strikes against the Assad regime following the August 2013 sarin attack in Ghouta irreparably damaged the credibility of the Coalition and the Western and Saudi-backed SMC among the rebel organisations on the ground ${ }^{44}$. Consequently, the most powerful organisations and their Qatari and Turkish backers denounced the Coalition and broke out the SMC to build an alliance of their own.

The motivation behind the creation the Islamic Front was that the alliance would gradually evolve into a single, centralised organisation aimed at establishing a theocratic rule ${ }^{45}$. Despite the grand ambitions, the amalgamation never materialised. Rather, the Islamic Front remained a relatively weakly structured alliance, unable to bridge the gap between the two dominant organisations within it, the Turkish and Qatari-backed Ahrar al-Sham and the Saudi-backed Jaysh al-Islam. An explosive proliferation of rebel organisations followed. The emergence and growth of new, powerful actors uprooted the FSA's hegemonic status, ushering in a period of multipolarity. While intra-rebel relations remained relatively amicable during Phase II, the rising powers were unable to form credible and durable alliances resulting in a relatively weak degree of institutionalisation within the movement (Figure 2). 
Figure 2: Fragmentation in Phase II

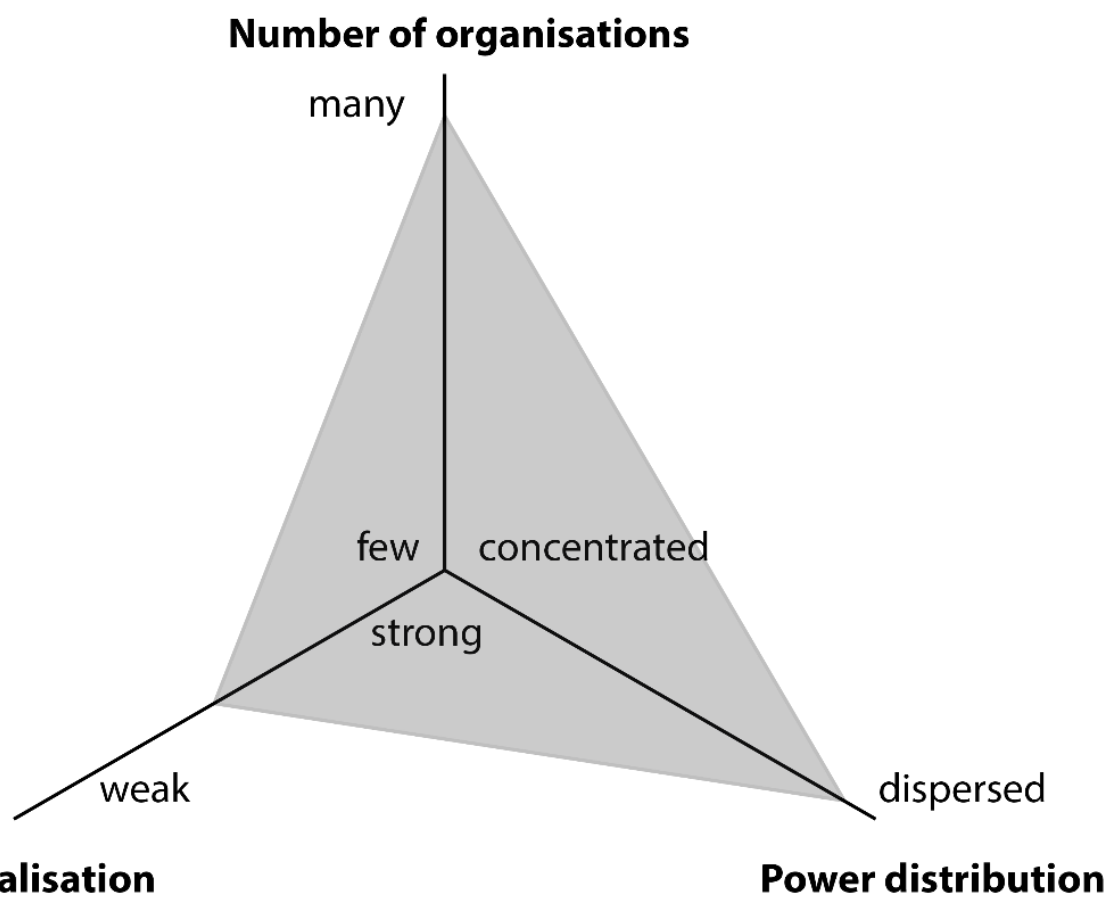

Phase III: Consolidation (August 2014 - December 2016)

The third phase of the conflict began with the creation of a new alliance built around Ahrar al-Sham and Jabhat al-Nusra. However, as the conflict became increasingly internationalised, the collaboration between the organisations also became strained, manifesting itself as widespread infighting among ostensibly allied organisations.

\section{The movement contracts}

On the 22nd of March 2015, Ahrar al-Sham and Suqour al-Sham, two of Syria's largest and most well established organisations, announced a complete merger of their forces ${ }^{46}$. Calling on all factions in Syria to unify their ranks, the announcement of the unification marked the latest in a series of mergers. During the fall of 2014, Ahrar al-Sham had absorbed Liwa alHaqq and the Kurdish Islamic Front, both of whom, like the newly absorbed Suqour al-Sham, had been part of the now defunct Islamic Front alliance. The merger was part of a deliberate policy implemented by the new leadership of Ahrar al-Sham, mirroring its constructive and pragmatic approach to cross-factional collaboration across the rebel movement's ideological spectrum. This expansive strategy of mopping up smaller organisations proved more fruitful than alliance building with equally dominant partners, as the gradual collapse of the Islamic Front had illustrated. 
Turkey and Qatar allegedly supported this policy in an attempt to counterbalance the influence of Jabhat al-Nusra on Turkey's border ${ }^{47}$. While Ahrar al-Sham had been cooperating very closely with the Syrian al-Qaeda affiliate throughout the conflict, it had nonetheless remained apprehensive towards Jabhat al-Nusra as it began employing increasingly harsh methods in the areas under its control, spurring Ahrar al-Sham's leader to denounce "values that contradict those we started within the revolution" 48 .

By successfully embedding itself into the wider rebellion through a highly pragmatic longterm strategy, Jabhat al-Nusra began to assert its authority on Western-backed FSA sub-factions. In a show of force, Jabhat al-Nusra attacked two FSA factions in Idlib province late October 2014 whom Abu Mohammed al-Jolani, the leader of Jabhat al-Nusra, regarded as corrupt American proxies intending to undermine the collaboration between Jabhat al Nusra and internationally accepted Salafi groups such as Ahrar al-Sham and Suqour al-Sham. A month before Jabhat al-Nusra's attack, the U.S. State Department had begun targeting Jabhat al-Nusra as an extension of the air campaign against ISIS due to its ties to al-Qaeda ${ }^{49}$.

\section{Ad-hoc alliance-building, part 2}

In March 2015, the Jaysh al-Fatah alliance, which included Jabhat al-Nusra, was created on the initiative of Ahrar al-Sham. Throughout the conflict, Ahrar al-Sham had managed to bridge the gap between organisations of different ideological preferences ${ }^{50}$. Within days after launching its offensive in Idlib, the newly formed coalition had driven the regime's forces out of the provincial capital, demonstrating a level of tactical inter-rebel coordination that had arguably not been seen before in Syria.

The advantages of collaborating across organisational divides sparked similar attempts in southern Syria where the Southern Front, an organisation comprised of FSA remnants, tried to capture Daraa city supported by Ahrar al-Sham, Jabhat al-Nusra and Jaysh al-Islam ${ }^{51}$. The newfound unity within the resurgent rebel movement also led to a closer alignment among its state backers in the region who, for the first time since the onset the conflict, appeared to act in relative unison. However, as the prospect of the fall of the Assad regime increased, outside forces soon interfered in Syria's civil war, thus stress testing the new alliance and increasing the pressure on its regional backers. 


\section{The Jabhat al-Nusra conundrum}

In September 2015, Russia intervened on behalf of Bashar al-Assad, effectively resetting the military balance in Syria ${ }^{52}$. With Russia entering the fray, all organisations within the rebel movement suddenly faced a materially superior enemy. Heavy rebel losses led to the adoption of a cessation of hostilities agreement, which explicitly excluded Jabhat al-Nusra due to its affiliation to al-Qaeda ${ }^{53}$. With Jabhat al-Nusra effectively isolated, airstrikes continued to target their forces and infrastructure in northwestern Syria. The isolation of Jabhat al-Nusra served as an attempt to sever the institutional links that had been forged between the organisations within the negotiation framework and the Jihadist organisation outside it, thus weakening Jabhat al-Nusra's sway over the remaining rebel organisations.

While Bakke et al. exclude the processes around peace settlements as factor influencing fragmentary dynamics, international stakeholder do at times implement strategies of intentional fragmentation in order to minimise the set of demands to be incorporated in a potential peace settlement ${ }^{54}$. By isolating the elements of a rebel movement who are least prone to compromise, reaching a political settlement with the others who are willing to accept the premise of negotiated political transition may be easier. However, the isolation of certain veto players from an international conflict resolution effort is also a risky undertaking, which may derail the entire process ${ }^{55}$. Thus, when the subsequent peace negotiations in Geneva began in April 2016, the most powerful actor on the ground, Jabhat al-Nusra, was not included in the talks, leaving it exposed to aerial attacks from American, Russian and Syrian jets.

Initially, the attempt by the international stakeholders to split the rebel movement appeared successful. Jabhat al-Nusra reacted violently to the deal, referring to the nominal allies who participated in the establishment of the cessation of hostilities agreement as "traitors of the revolution" ${ }^{56}$. Jabhat al-Nusra forcefully dispersed pro-FSA demonstrations in Idlib $^{57}$ and ransacked a U.S.-backed FSA faction. Elsewhere, in the besieged Damascene enclave of eastern Ghouta, Jabhat al-Nusra and Faylaq al-Rahman attacked the positions of Jaysh al-Islam, whose leadership headed the rebels' Geneva-delegation. Inside the enclave, rumours had been swirling that Jaysh al-Islam had facilitated the visit of a Russian military delegation, thus exacerbating the tensions between the local super-group and Jabhat al-Nusra, who had assumed that any peace deal with come at its expense ${ }^{58}$. Once widespread infighting broke out in Ghouta in April 2016, the inter-rebel civil war lasted for weeks and claimed the lives of several hundred fighters ${ }^{59}$. 
The cessation of hostilities and the attempt by international stakeholders to sideline Jabhat alNusra had shown that it was willing to assert its dominance against its nominal allies. It had come at a price, though; its antics had tarnished its name and spurred criticism from close allies, including Ahrar al-Sham. However, as the ceasefire gradually crumbled and the Geneva negotiations once again halted, Jabhat al-Nusra's view was arguably vindicated. Not only had it managed to position itself as the "real" protector of the Syrian revolution as it had continued its fight against the regime; the breakdown of the ceasefire also illustrated that the Jabhat al-Nusra had successfully rendered the rest of the rebel movement militarily dependent on its capabilities.

While Jabhat al-Nusra had weathered the storm, the ceasefire also showed that its isolated position was unsustainable. In an attempt to integrate itself deeper into the non-jihadist segment of the rebel movement, the organisation officially broke off its ties to the international alQaeda leadership in July 2016 in an attempt to rebrand the organisation as an explicitly Syrian organisation with "no relationship to any external entity"60. As Jabhat al-Nusra renamed itself Jabhat Fatah al-Sham, it commandeered a Jaysh al-Fatah offensive to break the siege of the rebel-held part of Aleppo in what appeared to be a vital victory for the rebel movement. Once again, the fruits of cross-organisational cooperation had been harvested. Unity, however, proved short-lived as the Russo-Syrian campaign to retake the city dealt a decisive blow to the rebel movement.

During the third phase of the conflict, the number of organisations dwindled as the amount of newcomers dropped significantly. Smaller organisations began to merge with Ahrar al-Sham, which absorbed three other organisations during the winter and fall of 2015 as the Syrian government's control over northwestern Syria began to crumble (Figure 3). The apparent weakness of the regime also fostered new institutional ties as old frameworks of cooperation dissolved. The creation of the Jaysh al-Fatah alliance marked the conflict's most successful attempt at institutionalising the struggle across the rebel movement. The unity manifested itself in the rebel-held areas as well as on the front lines, where several significant victories were attained. However, increased interference by outside forces and mounting international pressure threatened to upend the deepening links between non-Jihadist and Jihadist forces. 
Figure 3: Fragmentation in Phase III

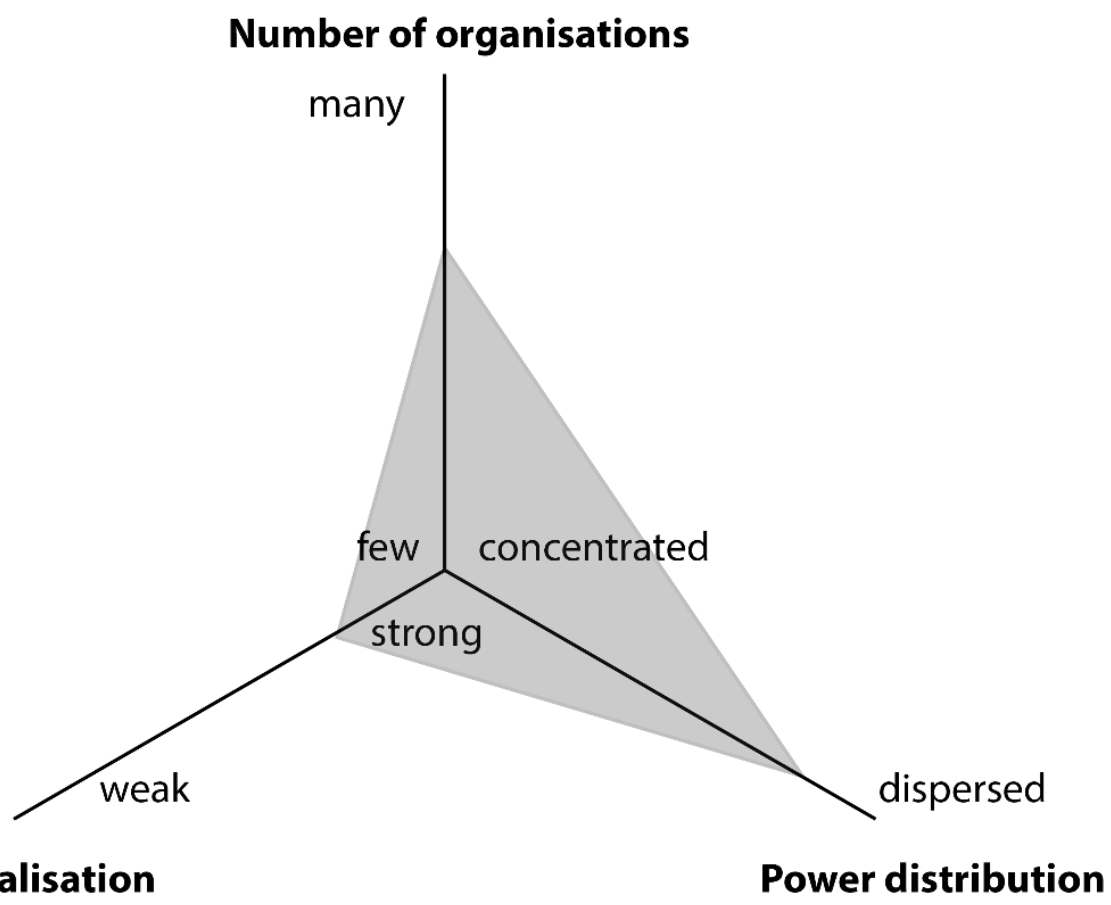

\section{Phase IV: Rupture (January - June 2017)}

In the fourth phase, the rebel movement fragmented completely. While the formation of Jaysh al-Fatah during Phase III had ushered in a period of intra-movement unity, cracks had begun to appear as external states attempted to isolate the Jihadist segments of the alliance. The fall of Aleppo became the catalyst that severed the institutional ties between the organisations and fragment the movement into two competing blocs of actors.

\section{Reshuffling the deck}

A noticeable tendency can be observed in the beginning of the fourth phase: Syria's rebel organisations suddenly began to coalesce into larger units. Rather than being numerically fragmented as was the case between 2012 and 2014, the number of organisations more than halved as smaller organisations began to merge into the organisational structures of Ahrar alSham and Jabhat al-Nusra. This evolution took place after the Syrian army and loyalist militias recaptured the rebel-held eastern part of Aleppo in December 2016. The fall of Aleppo marked a crushing military defeat and a political catastrophe for the rebel movement. It upended the status quo and undermined the relatively high degree of intra-movement coordination that had been established during the spring of 2015 . 
External state patrons enabled the sudden internal reordering of the rebel landscape in Syria, notably Turkey, who manipulated the internal composition of the movement in order to secure their own interests. Until the end of 2016, an increased degree of interdependency between the organisations within the Jaysh al-Fatah alliance had gradually developed, tying non-Jihadist and Jihadist organisations together. However, while Turkey had ostensibly endorsed the creation of the alliance on its border in order to pursue its goal of militarily defeating the Assad regime by proxy, Russia's entry into the war and YPG's territorial advances in northern and northeastern Syria gradually made Turkey change its calculus. Following the crushing rebel defeat in Aleppo, Ankara fully reoriented its Syria policy by reducing its commitment to the rebel organisations operating on its border and pushing for a negotiated settlement to the conflict in collaboration with Russia and $\operatorname{Iran}^{61}$. This rapprochement opened a wide rift within the movement, which set off the reordering of the rebel landscape.

A vocal minority within the Turkish-aligned Ahrar al-Sham had for some time pushed for a merger with Jabhat al-Fatah al-Sham, who had officially cut its ties to al-Qaeda five months earlier. Conversely, a majority within Ahrar al-Sham wanted to stay closely aligned to Turkey. This disagreement over the overall strategy of the organisation led to the formation of a splinter faction within the upper echelons of Ahrar al-Sham, which sought to unify the ranks of the rebel movement once and for all. Unable to bridge the divide between the two competing factions within Ahrar al-Sham's leadership, the subdued tensions eventually came to the surface as Jabhat Fatah al-Sham suffered increasingly heavy losses as a result of continued U.S. airstrikes ${ }^{62}$.

The catalyst that finally triggered the realignment of intra-movement relations were renewed attempts by Russia, Iran and Turkey to relaunch peace negotiations in the Kyrgyz capital of Astana. Facing military defeat, the non-jihadist organisations - excluding Ahrar al-Sham who nonetheless was accepted by Russia and Iran as a viable negotiating partner - agreed to participate in the rounds of negotiations in January 2017. Once again finding itself excluded by international actors in an attempt to isolate the terrorist-listed organisation, Jabhat Fateh alSham launched an offensive against a Western-backed FSA faction in Idlib.

Openly criticising the attack, Ahrar al-Sham released a written statement in which they warned their jihadist ally to cease the infighting: "We will join our brothers in the rest of the factions ... to prevent the Jabhat Fateh al-Sham columns to go [sic] and attack Muslims and 
harass them and wrongfully take their blood and money"63. The statement further announced that the local Idlib branches of Jaysh al-Islam and the Levant Front as well as several smaller factions would merge into Ahrar al-Sham due to fears of being targeted next, warning that an attack by Jabhat Fatah al-Sham on any of them would be considered an act of war $^{64}$. A decisive rift within the movement thus opened.

\section{The Jihadist powerhouse}

A second event influenced the distribution of power within the movement. Inside the jihadist camp, a similar process of consolidation was taking place: on January 28 , two days after the Ahrar al-Sham-led merger, the formation of Hayat Tahrir al-Sham was announced. By absorbing Harakat Nour al-Din al-Zinki, Ansar al-Sham and a large number of high-ranking defectors from Ahrar al-Sham, Jabhat Fateh al-Sham suddenly tripled the amount of fighters under the new command structure ${ }^{65}$.

Organisations within a rebel movement often compete over winning the hearts and minds of overlapping constituencies in order to shape and determine the trajectory of the conflict once splits between common and private interests open up. The rebranding manoeuvre should be seen in that light. Hayat Tahrir al-Sham now openly pursued a more nationalist agenda aimed at "protecting the precepts and principles of the Syrian revolution", as a Hayat Tahrir alSham spokesperson said, from what it perceived to be treacherous elements within the movement wanting to secure a negotiated ending to the conflict ${ }^{66}$.

In effect, the two expansion initiatives effectuated by Ahrar al-Sham and the former al-Qaeda affiliate split the movement into two camps: the Turkish-aligned organisations who had secured a seat at the table in Astana and the newly-established Jihadist supergroup, which remained isolated from outside support and left open to continued attacks from the air.

\section{Collapse}

The rupture within the movement led to the collapse of the Jaysh al-Fatah alliance, leaving the rebels without any collaborative frameworks through which the struggle could be coordinated. Institutional decay triggered infighting among the dominant organisations as they increasingly begin to pursue private advantages and divergent interests pulled them apart. The prospect of transforming Jabhat al-Nusra into an internationally accepted party to the conflict through its successive rebranding manoeuvres had failed and Hayat Tahrir al-Sham began 
lashing out at its nominal allies. The movement first dealt isolated blows against Ahrar alSham and then confronted Jaysh al-Islam in the enclave of eastern Ghouta where an almost exact reprise of the April 2016 inter-rebel civil war played out in early May 2017. The fratricidal infighting claimed the lives of up to 170 fighters and civilians ${ }^{67}$, spurring large numbers of residents to take to the streets, protesting the widespread clashes. The Syrian army exploited the internal clashes by launching an offensive north of the Ghouta suburbs and captured significant territories as the rebel forces continued to clash inside the besieged enclave.

Provoked by outside forces, a rupture within the Syrian rebel movement opened up a faultline, which effectively split the movement. In June 2017, the movement consisted of numerous organisations, no institutional links between them and power distributed between two competing centres of gravity, Ahrar al-Sham and Hayat Tahrir al-Sham (Figure 4). As Bakke et al. ${ }^{68}$ note, movements suffering from an extreme degree of fragmentation are very likely to engage in widespread, localised infighting. As an omen of what may will become a wider trend, the rebel-held enclave of eastern Ghouta once again broke apart in yet another bout of infighting, while the formerly close rebel allies in Idlib province tread a thin line between fragile peace and potentially devastating inter-rebel conflict.

Figure 4: Fragmentation in Phase IV

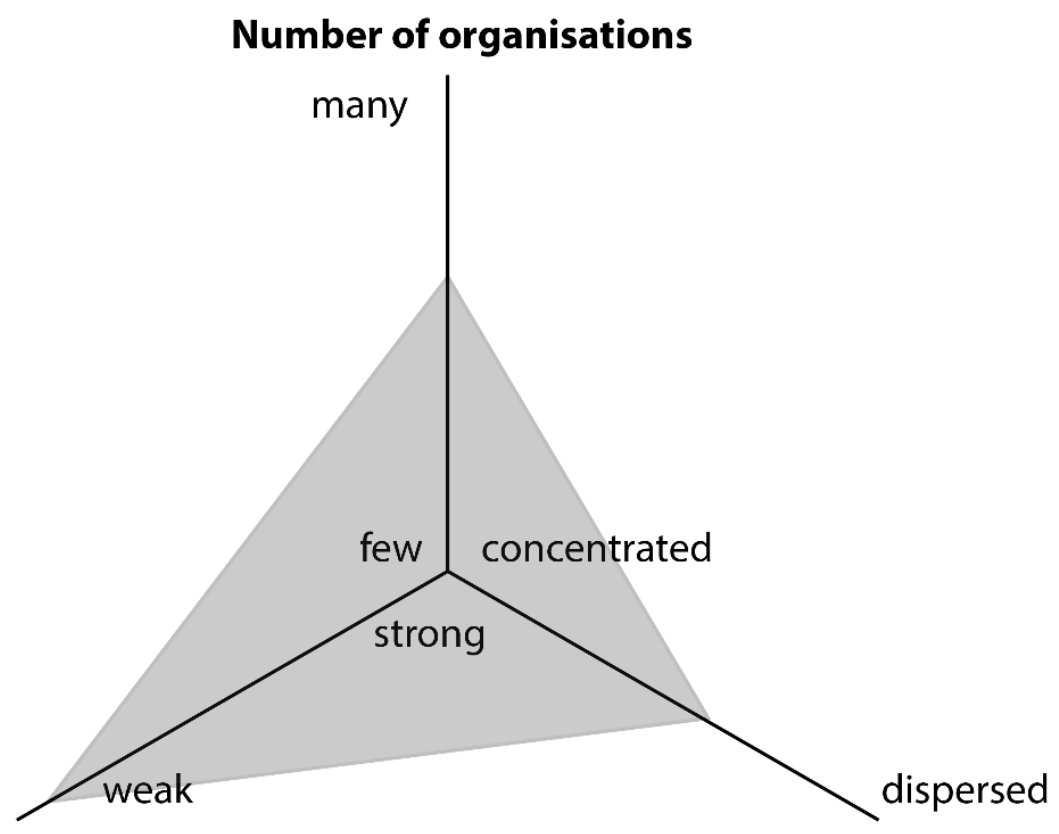




\section{Discussion}

\section{Causal mechanisms of rebel fragmentation}

The evolution of the Syrian conflict from 2011 to 2017 suggests that the causal mechanisms of rebel fragmentation are both endogenous and exogenous. Structural preconditions and the credibility gap are among the most crucial endogenous factors. The circumscribed state of the pre-war political opposition, the absence of independent institutions and the state's co-optation of Syria's civil society organisations severely thwarted the way in which the widespread discontent with the Syrian regime could manifest itself at the onset of the conflict. In the absence of pre-existing institutions through which the uprising could be organised, the rebellion sprouted spontaneously through neighbourhood militias, cell-based rebel networks and makeshift committees riddled by parochial power struggles and local agendas.

The absence of trust between the rebels on the ground, the exiled politicians and the dissidents within the SNC also left the political opposition body with a weak mandate and insufficient legitimacy to exercise political authority within Syria. Unable to formulate a coherent vision for the future of the Syrian state, the SNC failed to unify the increasingly disparate FSA sub-factions as they gradually broke away from the command structure. Despite attempts to revive the dysfunctional opposition body through the creation of the Coalition, the gulf between the rebel organisations and their political representatives in Turkey could not be effectively bridged, leaving the rebel organisations at the helm of external powers.

Exogenous factors also played a key role, particularly the lack of donor coordination, intraregional competition and reorientation of patron policies. The sporadic manner in which the regional backers provided financial and lethal assistance to the rebel movement undermined the SMC's coordinating role and undercut the hegemony of FSA as the number of rebel organisations proliferated during the conflict's second phase. In northwestern Syria, the lack of donor coordination manifested itself on the ground as a complex web of overlapping, hyperlocalised zones of influence. In southern Syria, where Jordan strictly controlled its distribution networks, the rebel landscape remained relatively cohesive as exemplified by the formation of the Southern Front.

The geopolitical context in which the conflict is embroiled injected external interests into the rebel movement. Saudi Arabia and Qatar's rivalry over the trajectory of the conflict opened rifts between the nominally allied organisations. While it would be inaccurate to characterise 
the rebel organisations as state proxies, their dependence on fluctuating funding streams from Turkey, Saudi Arabia and Qatar undermined attempts to form credible alliances and govern the rebel-held areas efficiently. This opened a window of opportunity for Jabhat al-Nusra to embed itself into Syria's social fabric.

As exemplified by Turkey's rapprochement with Russia and Iran after the fall of Aleppo, the interdependency forged between the non-jihadist elements of the Syrian rebel movement and Ankara lead to a near total collapse of unity between the dominant organisations as Jabhat alNusra was politically and diplomatically sidelined. Divided over the contentious issue and effectively splitting the movement into two competing camps, Ahrar al-Sham and its allies aligned with Turkey while other organisations sided with the Jihadist organisation, leading to the creation of Hayat Tahrir al-Sham.

A common denominator of the causal mechanisms of rebel fragmentation identified in Syria is that they are second-order effects of actions and dynamics outside the immediate control of the rebel organisations themselves. The numerical proliferation and contraction of organisations, sudden changes in power distribution and violent breakdowns of alliances are not the result of intentional actions pursued by the non-state actors. While organisations possess varying propensities and abilities to manoeuvre within this fragmented rebel landscape and, to some extent, counteract the negative constraints the context of the conflict imposes on the armed actors, the dynamics that trigger fragmentation are embedded in the historical, structural and geopolitical context in which the conflict occurs.

\section{A maximum winning coalition?}

The evolution of the Syrian conflict suggests that rebel groups exercise little control over the dynamics that shape their ability to cultivate intra-movement coherence. In fact, all the dominant rebel organisations have attempted to forge a stronger degree of institutionalisation among themselves through alliances and mergers. In particular, the formation of the Jaysh alFatah alliance in the spring of 2015 illustrated that several dominant rebel organisations (Ahrar al-Sham and Jabhat al-Nusra) do possess the capacity and as well as the willingness to engage in collaboration. However, dynamics outside the immediate control of the organisations seem to have undermined and obstructed the inner-workings of the alliances in several ways. 
In the case of Jaysh al-Fatah, the Syrian army's recapturing of Aleppo caused Turkey to reorient its Syria policy, thus spurring Ankara to salvage their own rebel partners on the ground while leaving Jabhat al-Nusra isolated and open to continued attacks.

These findings contrast with Christia's ${ }^{69}$ study of alliance formation and rebel fragmentation in Bosnia and Afghanistan that suggest that rational power considerations drive the formation and fracturing of rebel alliances. According to this view, rebels want to be part of a coalition large enough to attain victory while small enough to ensure maximum political payoffs in a post-conflict scenario. The implication of this dilemma is that unless one organisation is sufficiently powerful to attain victory over the incumbent state on its own, the conflict will degenerate into a constant process of alliance reconfigurations as the rebels manoeuvre to win the war while simultaneously ensuring that they do not become the victim of the winning party. Consequently, the inner-workings of rebel movements are shaped by intentional actions by the individual organisations through a 'minimum winning coalition' logic.

A possible explanation for the divergent results between this approach and our results may be found in the nature and context of the conflicts themselves. The 'minimum winning coalition' theory builds upon meticulous case studies of intra-rebel-movement relations in the successive Afghan civil wars between 1978 and 1998, the Bosnian civil war spanning from 1992 until 1998 as well as the Bosnian civil war of 1992 and during World War II. A common denominator in these conflicts is an extreme degree of ethnic and sectarian heterogeneity among the warring actors. Ruling elites manipulate identity narratives to accommodate the formation of new intergroup alliances based on relative power considerations. This explains why Shiite Hazaras and Sunni Pashtuns in Afghanistan, for example, may ally at one point during a conflict and find themselves engaged in all-out battle in the next moment as new alliance partners emerge and power distribution among the organisations shift.

In contrast, the rebel movement in Syria mainly consists of people of Arab descent, predominantly hailing from the poor and underdeveloped rural provinces of Syria and is overwhelmingly Sunni-dominated. There is a relatively high degree of socio-cultural, sectarian and ethnic homogeneity within the movement. While we can observe shifts in alliance preferences among the rebel organisations in Syria, they do not appear to be motivated by a 'minimum winning coalition' logic. Rather, the pattern of alliance formation in Syria indicates that the organisations have sought to cultivate coalitions based on a 'maximum winning coalition' 
logic encompassing several dominant organisations with relatively similar ideological preferences. The formation of Jaysh al-Fatah during the third phase of the conflict constitutes an example of pragmatic Salafist and more dogmatic Jihadist alliance building. While they do remain divided over issues such as to which extent social control should be enforced in the rebel-held areas, they nonetheless share very similar conceptions of how a strict Islamic system of governance should be implemented.

\section{Conclusions}

More than seven years after hundreds of thousands of protesters took to the streets demanding political, economic and social reforms, Syria's civil war grinds unabatedly on. Marred by internal divisions stemming from and exacerbated by historical, structural and geopolitical constraints, the rebel movement has effectively split into two competing centres of gravity that tread a thin line between fragile peace and potentially devastating inter-rebel conflict. Reeled in by Turkey's seismic policy shift after its incursion into northern Syria and the fall of Aleppo, Ahrar al-Sham and its allies have seen themselves forced to accept a negotiated settlement in order to salvage what they believe is left of the rebellion. In February 2018, they merged with the Nour al-Din al-Zenki Movement, previously allied with Hayat Tahrir alSham, to form the Syrian Liberation Front.

Meanwhile, Hayat Tahrir al-Sham, effectively isolated by the international community, remains defiant and stronger than ever before as Jabhat al-Nusra has successfully absorbed a range of medium-sized organisations. The failure of Syria's rebel movement to coalesce during the early days of the insurgency has played into the hands of the Jihadist components of the movement to seize control of the uprising through superior organisational structures, cool-headed pragmatism and non-reliance on patron policies.

Where does this lead? The current fragmentation of the rebellion suggests that the Syrian regime is likely to survive and will show no willingness to compromise. Idlib province, the rebel's strategically vital stronghold, is likely to remain under shared albeit strained control by Ahrar al-Sham and Hayat Tahrir al-Sham. The degree to which Hayat Tahrir al-Sham has successfully integrated itself into the social fabric of rebel-held Idlib indicates that the organisation will remain a highly influential player in the years to come as it attempts to realise its vision of establishing a de-facto Islamic emirate in the Turkish-Syrian borderlands. Not unlike the way in which the Taliban in Afghanistan have successfully resisted more than 15 
years of extensive counterinsurgency campaigns, the international community may see itself forced to accepting Hayat Tahrir al-Sham as a negotiating partner. For as long as the Syrian army is unable to recapture the rebel stronghold by force and Turkey tacitly accepts the Jihadist presence on its border, Hayat Tahrir al-Sham is not likely to disappear.

The Syrian tragedy serves as a stark reminder of the dangers and pitfalls of waging war by proxy. Not only has the concerted effort to arm Syria's rebels in order to install a Sunni client in Damascus descended into internecine rivalry between the nominally allied regional powers; the external backers also seem to have severely underestimated the difficulty of controlling the overall trajectory of the conflict. Will Syria ever be able to reconstitute itself as a territorially, socially and politically coherent unit? The prospects are bleak as its fragmented, ungovernable lands are likely to remain criss-crossed by sectarian, ethnic, social and geopolitical cleavages.

\footnotetext{
${ }^{1}$ Michael Findley and Peter Rudloff, "Combatant Fragmentation and the Dynamics of Civil Wars," British Journal of Political Science 4, (2012: 879-901; Kristen Bakke, Kathleen G. Cunningham, Kathleen and Lee Seymour, "E pluribus unum, ex uno plures: Competition, Violence and Fragmentation in Ethnopolitical Movements," Journal of Peace Research 53, no. 1 (2016): 3-18.

${ }^{2}$ Kathleen G. Cunningham and Wendy Pearlman, "Non-state Actors, Fragmentation, and Conflict Processes," Journal of Conflict Resolution 56, no. 1(2012): 3-15; Paul Staniland, Networks of Rebellion - Explaining Insurgent Cohesion and Collapse (Ithaca: Cornell University Press, 2014); Charles W. Mahoney, "Splinters and Schisms: Rebel Group Fragmentation and the Durability of Insurgencies," Terrorism and Political Violence (2017): 1-20; Olivier Walther, Christian Leuprecht, and David B. Skillicorn. "Political Fragmentation and Alliances among Armed Non-state Actors in North and Western Africa (1997-2014)," Terrorism and Political Violence (2017): 1-20.

${ }^{3}$ Kathleen G. Cunningham, "Divide and Conquer or Divide and Concede: How Do States Respond to Internally Divided Separatists?” American Political Science Review 105, no. 2(2011): 275-297.

${ }^{4}$ See Kristen Bakke, Kathleen G. Cunningham, Kathleen and Lee Seymour, “A Plague of Initials: Fragmentation, Cohesion and Infighting in Civil Wars," Perspectives on Politics 10, no. 2 (2012a): 265-283; Kristen Bakke, Kathleen G. Cunningham, Kathleen and Lee Seymour, "Shirts Today, Skins Tomorrow: Dual Contests and the Effects of Fragmentation in Self-Determination Disputes," Journal of Conflict Resolution 56, no. 1 (2012b): 67-93.

${ }^{5}$ Hanne Fjelde and Desiree Nilsson, "Rebels against Rebels: Explaining Violence between Rebel Groups", Journal of Conflict Resolution 56, no. 4 (2012): 604-628; Hanne Fjelde and Desiree Nilsson, "The Rise of Rebel Contenders: Barriers to Entry and Fragmentation in Civil Wars," Journal of Peace Research (2017).

${ }^{6}$ Fotini Christia, Alliance Formations in Civil Wars (Cambridge: Cambridge University Press, 2012).

${ }^{7}$ Michael Findley and Peter Rudloff, "The Downstream Effects of Combatant Fragmentation on Civil War Recurrence," Journal of Peace Research 53, no. 1 (2016): 19-32.

${ }^{8}$ Claire M. Metelits, "The Consequences of Rivalry: Explaining Insurgent Violence Using Fuzzy Sets," Political Research Quarterly 62, no. 4 (2009): 673-684.

${ }^{9}$ David Cunningham, "Veto Players and Civil War Duration," American Journal of Political Science 50, no. 40 (2006): 875-892.

${ }^{10}$ Seden Akcinaroglu, "Rebel Interdependencies and Civil War Outcomes," Journal of Conflict Resolution 56, no. 5 (2012): 879-903.

${ }^{11}$ Fjelde and Nilsson (2012: 605).

${ }^{12}$ Fjelde and Nilsson (2017).

${ }^{13}$ Christia (2012).

${ }^{14}$ Christia (2012: 240).

${ }^{15}$ Bakke et al. (2012a).

${ }^{16}$ Bakke et al. (2012a).
} 
${ }^{17}$ Bakke et al. (2012a).

${ }^{18}$ Wendy Pearlman, "Rebel Fragmentation in Syria and Palestine," Foreign Policy, October 10, 2013.

${ }^{19}$ Javier Osorio, "Numbers Under Fire: The Challenges of Gathering Quantitative Data in Highly Violent Settings," Drug, Security and Democracy Working Papers on Research Security, vol. 6 (2014).

${ }^{20}$ Stanford University, "Mapping Militant Organizations: Syria” http://web.stanford.edu/group/mappingmilitants/cgi-bin/maps/view/syria (accessed June 12, 2018).

${ }^{21}$ International Crisis Group, "Anything But Politics: The State of Syria's Political Opposition", Crisis Group Middle East Report 146, 17 October 2013.

22 Samer N. Abboud. Syria (Cambridge: Polity, 2016).

${ }^{23}$ Aron Lund, "Divided They Stand: An Overview of Syria's Political Opposition Factions" (Uppsala: Foundation for European Progressive Studies, 2012).

${ }^{24}$ Charles Lister, The Syrian Jihad - al-Qaeda, The Islamic State and the Evolution of an Insurgency (London: Hurst, 2015), 343.

${ }^{25}$ Lund, Aron. "Syria's Salafi Insurgents: The Rise of the Syrian Islamic Front", UI Occasional Papers, Swedish Institute of International Affairs, vol. 17, 2013: 11.

${ }^{26}$ Emile Hokayem, "Syria's Uprising and the Fracturing of the Levant" (International Institute for Strategic Studies, London, 2013).

${ }^{27}$ Doreen Khoury, "Losing the Syrian Grassroots", (Berlin, German Institute for International and Security Affairs, 2013).

${ }^{28}$ Rania Abouzeid, “A Dispatch from ‘Free' Syria: How to Run a Liberated Town,” Time Magazine, July 24, 2012.

${ }^{29}$ Samer N. Abboud, "Conflict, Governance and Decentralised Authority in Syria," in The Levant in Turmoil, edited by Martin Beck, Dietrich Jung and Peter Seeberg (Basingstoke, Palgrave, 2016), 57-77.

${ }^{30}$ Lund (2012: 61).

${ }^{31}$ Klaus Schlichte and Ulrich Schneckener, "Armed Groups and the Politics of Legitimacy," Civil Wars 17, no. 4 (2015): 409-424.

${ }^{32}$ Christopher Phillips, The Battle for Syria - International Rivalry in the New Middle East (New Haven: Yale University Press, 2016): 106.

${ }^{33}$ International Crisis Group (2013: 10)

${ }^{34}$ Reuters, "Eleven Killed in Syria on Eve of Arab Deadline," November 18, 2011.

${ }^{35}$ Sarah Leah Whitson, "Open Letter to the Leaders of the Syrian Opposition Regarding Human Rights Abuses by Armed Opposition Members," Human Rights Watch, March 20, 2012.

${ }^{36}$ Phillips (2016: 115).

${ }^{37}$ Lund (2013: 24).

38 SANA, "Syria's Armed Opposition: A Spotlight at the 'Moderates"” (Geneva: Small Arms Survey, 2016$), 4$.

${ }^{39}$ Abboud (2016: 125).

${ }^{40}$ Phillips (2016).

${ }^{41}$ Bakke et al. (2012a).

${ }^{42}$ Akcinaroglu (2012: 880).

43 Aron Lund, "The Politics of the Islamic Front, Part 1: Structure and Support" and "Part 2: An Umbrella Organization,” (Beirut, Carnegie Middle East Center, 2014).

${ }^{44}$ Lister (2015: 12).

${ }^{45}$ Lund (2013).

${ }^{46}$ Aron Lund, "Islamist Mergers in Syria: Ahrar al-Sham Swallows Suqour al-Sham." (Beirut, Carnegie Middle East Center, 2015).

${ }^{47}$ Lund (2015).

${ }^{48}$ Lister (2015: 343)

49 BBC, "What is the Khorasan Group?" BBC News, September 24, 2014.

${ }^{50}$ Phillips (2016: 215).

${ }^{51}$ Phillips (2016: 216).

52 Geneviève Casagrande, Christopher Kozak and Jennifer Cafarella, "Syria 90-day Forecast: the Assad Regime and Allies in Northern Syria," (Washington, DC: Institute for the Study of War, 2016).

${ }^{53}$ United Nations Security Council Resolution 2254, December 18, 2015.

${ }^{54}$ Cunningham (2011: 275-297).

55 Cunningham, D (2006: 875-892).

${ }^{56}$ Félix Legrand, "The Strategy of Jabhat al-Nusra/Jabhat Fath al-Sham Regarding the Truces in Syria," NORIA, 2016.

${ }^{57}$ Osama Abu Zeid, "Nusra Deflects Blame for Protest Suppression; 'Mandate Flag Sows Division'," Syria Direct, March 8, 2016. 
${ }^{58}$ Aron Lund, "Into the Tunnels - The Rise and Fall of Syria's Rebel Enclave in the Easter Ghouta," (New York City, The Century Foundation, 2016).

59 Tadrous Al-Basel and Mahmoud Zuhuor, “Ghouta Infighting Challenges Jaish al-Islam's Rule,” Syria Deeply, June 1, 2016.

${ }^{60}$ Hassan, "Syrian War Enters a New Phase as Factions Realign," The National, August 7, 2016.

${ }^{61}$ Aron Lund, "The Jihadi Spiral," (Beirut, Carnegie Middle East Center, 2017).

${ }^{62}$ Aymenn Al-Tamami, "The Formation of Hay'at Tahrir al-Sham and Wider Tensions in the Syrian Insurgency," Combating Terrorism Center Sentinel 10, no. 1 (2017), 17.

${ }^{63}$ Alex MacDonald, “Analysis: Why Jabhat Fatah al-Sham Is Lashing Out at Syrian Rebels," Syria Deeply, January 27, 2017.

${ }^{64}$ Mariya Petkova, "Syrian Opposition Factions Join Ahrar al-Sham,” Al Jazeera, January 28, 2017.

${ }^{65}$ Allegedly, Hayat Tahrir al-Sham has up to 31.000 fighters under its direct control. See Mattisan Rowan, "Al Qaeda's Latest Rebranding: Hay'at Tahrir al Sham”, (Washington, DC, The Wilson Center, 2017).

${ }^{66}$ Al-Tamami (2017: 18).

${ }^{67}$ Syrian Observatory for Human Rights, “A Week of Clashes Kills about 170 Civilians and Fighters in the Eastern Ghouta," 5 May 2017.

${ }^{68}$ Bakke et al. (2012a: 277).

${ }^{69}$ Christia (2012). 